\title{
Outcome and Radiotherapy Side Effects of High-Risk Endometrial Cancer
}

Brahmana A skandar Tjokroprawiro ${ }^{1 *}$, Lulus Handayani², M. Dimas Abdi Putra ${ }^{3}$

${ }^{1}$ Oncology Division, Department of Obstetrics and Gynecology, Faculty of Medicine-Dr. Soetomo Teaching Hospital, Universitas Airlangga, Surabaya 60131, Indonesia

${ }^{2}$ Department of Radiotherapy, Faculty of Medicine-Dr. Soetomo Teaching Hospital, Universitas Airlangga, Surabaya 60131, Indonesia

${ }^{3}$ Department of Obstetrics and Gynecology, Faculty of Medicine-Dr. Soetomo Teaching Hospital, Universitas Airlangga, Surabaya 60131, Indonesia

\section{Article History: \\ ABSTRACT \\ The endometrial cancer is radiosensitive. Adjuvant radiotherapy is previously said that it may improve survival rate of high-risk endometrial cancer and decrease recurrences rate. This study evaluated overall survival, disease-free survival (DFS) in high risk endometrial cancer, and postradiotherapy side effects. Analytic retrospective research using medical record was conducted. During the 2013-2018 period there were 185 patients with endometria cancer undergoing radiotherapy. Prognostic factors for OS which are statistically significant were age, BMI, LVSI, stage, waiting time interval, and recurrence. The prognostic factor group of age $>60$ years significantly had OS $(p=0.04)$ and DFS-3 years $(p=0.03)$ which was better than that of the age group $<60$ years. Obese patients had OS $77 \%$ better than the non-obese group $(p=0.02)$. The LVSI positive group significantly had OS $0 \%$ with OR of $0.3(95 \% \mathrm{Cl} 0.1-0.8)(\mathrm{p}=$ $0.02)$ and DFS-3 years $50 \%(p=0.004)$. Patients with waiting time}

\section{INTRODUCTION}

Endometrial cancer is one of the mortality causes of women worldwide with 200,000 new cases a year (1). The endometrial carcinomas areclassified as Typel endometrioid endometrial carcinomas (EECS) and Type II nonendometrioid endometrial carcinomas (NEECs) $(2,3)$. In 2016, there were 120 patients of endometrial cancer treated in dr. Soetomo Hospital, Surabaya (4). H igh-risk endometrial cancers are those which endometrioid type grade 3 stage Ib, clear cell carcinoma, serous carcinoma, and stages III and IV $(1,5)$. In addition, women who are diagnosed with epithelial ovarian cancer (EOC) can suffer endometrial premalignancies, and women with endometriosis haverisk to endometrial cancer, whereas the Natural Kill (NK) cell is lower $(6,7)$. Morever, vascular endothelial growth factor (VEGF) is angiogenic factor which plays important roles in the growth of endometrial cancers (8).

Hysterectomy with bilateral salphyngo-oophorectomy is a treatment of choice, and adjuvant radiotherapy probably has benefit (9). Generally, endometrial cancer is radiosensitive. Adjuvant radiotherapy is previously said that may improve survival rate of high-risk endometrial cancer and decrease recurrences rate. Previously known prognostic factors of endometrial cancer are stage, age, histologic type, grade, invasion, and lympho-vascular space invasion (LVSI) $(10,11)$. Radiotherapy may also make adverse effects. Diarrhea, urine retension due to urethra stricture, and fecal incontinentia are some of adverse effects post-radiotherapy of gynecologic cancer (12).

One problem which is frequently found in $\mathrm{dr}$. Soetomo General Hospital, Surabaya is long queues. A previous research was explained that the interval time between postoperation to radiotherapy could affect outcome and cancer progressivity (13). Until this article written, there are no data
Revised: 07.04 .2020

Accepted: 11.05 .2020

intervals (queue) $>9$ weeks had OS $35 \%(p=0.03)$ with OR of 3.2 (95\% Cl 1.1-8.8), and lower DFS-3 years (76\% vs $91 \%$; $p=0.03$ ). Combination of radiotherapy modalities caused $61 \%$ of side effects, but statistically not significant. OS and DFS-3 years in patients $>60$ years old and obese were better than $<60$ years of age and non-obese. Positive LVSI group had poorer OS and DFS-3 years. The more side effects were due to the combination of modality.

Keywords: endometrium, high risk, radiotherapy

Correspondance:

Brahmana Askandar Tjokroprawiro

Oncology Division, Department of Obstetrics and Gynecology, Faculty of Medicine-Dr. Soetomo Teaching Hospital, Universitas Airlangga, Surabaya 60131, Indonesia

Email: brahmanaaskandar@gmail.com

DOI: $10.31838 /$ srp. 2020.5 .29

@Advanced Scientific Research. All rights reserved

of outcome of post-radiotherapy high-risk endometrial cancer in dr. Soetomo H ospital for evaluation. Besides, there was affective psychopathological comorbidities affecting on the quality of life of patients who are undergoing radiotherapy (14). The aim of this study was to evaluate overall survival, disease-freesurvival in high risk endometrial cancer, and postradiotherapy side effects.

\section{METHODS}

This was an analytic retrospective study using medical record of post-radiotherapy high-risk endometrial cancer patients who underwent radiotherapy in $\mathrm{dr}$. Soetomo General Hospital, Surabaya. The inclusion criteria in this study were high-risk endometrial cancer and having been done radiotherapy. Whereas, the exclusion criteria were incomplete required data, incomplete radiotherapy, and suffering from another cancer. The outcomes of this study were overall survival, disease-free survival, and adverse effects of radiotherapy. $V$ ariables of prognostic factors which were also evaluated are age, body mass index (BM I), parity, histopathology, stage, LVSI, history of lymphadenectomy, interval time, recurrences, and radiotherapy modality. Survival analysis was done using Kaplan-M eier. Log-rank test was performed for univariate analysis, cox regression was performed to evaluate time-dependent correlation among variables, and logistic regression was performed to evaluate correlation among variables without any specific time.

\section{RESULTS \\ Characteristics}

M edical record that had been donefound 185 medical record of endometrial cancer patients who underwent radiotherapy in dr. Soetomo Hospital, Surabaya during period of 2013- 
2018. Inclusion criteria were applied, and 77 patients met the criteria.

Classification of characteristics was done according to some parameters as seen in Table 1. Most frequent use of radiotherapy modality in this study was combination of EBRT and brachytherapy. In this study, three patients were performed primary radiotherapy due to medically unfit for surgery. Radiotherapy modality for those three patients was EBRT only. One patient in this study performed only brachytherapy due to vaginal metastasis (stage III B).

Table 1: Patient characteristics

\begin{tabular}{|c|c|c|c|}
\hline \multirow[t]{2}{*}{ Characteristics } & \multirow[t]{2}{*}{$\mathbf{n}$} & \multirow[t]{2}{*}{$\%$} & \multirow{2}{*}{$\begin{array}{l}\text { Mean } \pm \text { SD / } \\
\text { Median (min- } \\
\text { max) }\end{array}$} \\
\hline & & & \\
\hline Age (years) & & & $57.56 \pm 8.19$ \\
\hline$<60$ & 41 & 53.2 & \\
\hline$\geq 60$ & 36 & 46.7 & \\
\hline Body $M$ ass I ndex $\left(\mathrm{kg} / \mathrm{m}^{2}\right)$ & & & $24.7 \pm 5.5$ \\
\hline$<30$ & 64 & 83.1 & \\
\hline$\geq 30$ & 13 & 16.8 & \\
\hline Parity & & & $2(0-9)$ \\
\hline Nuliparity & 16 & 20.7 & \\
\hline Multiparity & 61 & 79.3 & \\
\hline \multicolumn{4}{|l|}{ M enopausal state } \\
\hline M enopause & 72 & 93.5 & \\
\hline Not menopause & 5 & 6.5 & \\
\hline \multicolumn{4}{|l|}{ Histologic type } \\
\hline Endometrioid & 64 & 83.1 & \\
\hline Serous carcinoma & 5 & 6.4 & \\
\hline Clear cell carcinoma & 8 & 10.3 & \\
\hline
\end{tabular}

\begin{tabular}{lll}
\hline LVSI & 34 & 44.1 \\
Positive & 43 & 55.9 \\
N egative & & \\
Lymphadenectomy & 30 & 38.9 \\
Yes & 44 & 61.1 \\
No & & \\
Radiotherapy modality & 27 & 35.1 \\
$\quad$ EBRT & 1 & 1.2 \\
Brachytherapy & 49 & 63.7 \\
EBRT + Brachytherapy \\
Radiotherapy \\
$\quad$ Adjuvant & 74 & 96 \\
Primary & 3 & 4 \\
IV A & 1 & \\
IVB & 2 & \\
Pre radiation & & \\
chemotherapy & 40 & 52 \\
Yes & 37 & 48 \\
No & & \\
\hline
\end{tabular}

\section{Overall survival}

Overall survival analysis was performed in every variable as shown in Table 2. This study found 29 patient passed away with median time of passed away of 11 (Cl 95\% 2-43) month. M edian with $95 \% \mathrm{Cl}$ showed period of time in which $50 \%$ of patients passed away. For overall survival, variables which statistically significant were age, BMI, stage, LVSI, queueing duration, and history of recurrence. Overall survival in age group of $\geq 60$ was $61 \%$, and DFS-3 years was $82 \%$ ( $p<0.05$ ). Obese patients significantly had better overall survival than

Table 2: All variable results

\begin{tabular}{|c|c|c|c|c|c|c|c|}
\hline \multirow[t]{2}{*}{ Characteristics } & \multirow{2}{*}{$\begin{array}{l}\text { Alive (48) } \\
n(\%)\end{array}$} & \multirow{2}{*}{$\begin{array}{l}\text { Died (29) } \\
n(\%)\end{array}$} & \multirow{2}{*}{$\begin{array}{l}\text { OS } \\
(\%)\end{array}$} & \multirow[t]{2}{*}{ OR } & \multirow[t]{2}{*}{$\mathbf{p}$} & \multirow{2}{*}{$\begin{array}{l}\text { DFS-3years } \\
(\%)\end{array}$} & \multirow[t]{2}{*}{$\mathbf{p}$} \\
\hline & & & & & & & \\
\hline \multicolumn{8}{|l|}{ Age (years) } \\
\hline$<60$ & $23(56.3)$ & $18(43.7)$ & 39 & & \multirow[t]{2}{*}{$0.04 *$} & 78 & \multirow{2}{*}{$0.03^{* *}$} \\
\hline$\geq 60$ & $25(69.4)$ & $11(30.6)$ & 61 & & & 82 & \\
\hline \multicolumn{8}{|l|}{ BMI $\left(\mathrm{kg} / \mathrm{m}^{2}\right)$} \\
\hline$<30$ & $39(60.9)$ & $25(39.1)$ & 43 & & \multirow[t]{2}{*}{$0.02 *$} & 72 & \multirow[t]{2}{*}{ NS } \\
\hline$\geq 30$ & $11(84.6)$ & $2(15.4)$ & 77 & & & 100 & \\
\hline \multicolumn{8}{|l|}{ Parity } \\
\hline Nuliparity & $11(68.7)$ & $5(31.3)$ & 58 & & \multirow[t]{2}{*}{ NS } & 96 & \multirow{2}{*}{ NS } \\
\hline M ultiparity & $37(60.6)$ & $24(39.4)$ & 46 & & & 88 & \\
\hline \multicolumn{8}{|l|}{ M enopausal status } \\
\hline M enopause & $46(63.8)$ & $26(36.2)$ & 48 & & \multirow[t]{2}{*}{ NS } & 78 & \multirow{2}{*}{ NS } \\
\hline Not menopause & $2(40)$ & $3(60)$ & 80 & & & 100 & \\
\hline \multicolumn{8}{|l|}{ Histopathology } \\
\hline Endometrioid & $39(60.9)$ & $25(39.1)$ & 63 & & \multirow[t]{3}{*}{ NS } & 78 & \multirow{3}{*}{ NS } \\
\hline Serous carcinoma & $2(40)$ & $3(60)$ & 76 & & & 90 & \\
\hline Clear cell & $7(87)$ & $1(13)$ & & & & & \\
\hline \multicolumn{8}{|l|}{ LVSI } \\
\hline Positive & $23(67.6)$ & $11(32.4)$ & 0 & \multirow[t]{2}{*}{$0.3(0.1-0.8)$} & \multirow[t]{2}{*}{$0.02 * *$} & 50 & \multirow{2}{*}{$0.004 * *$} \\
\hline Negative & $25(58.1)$ & $18(41.9)$ & 68 & & & 95 & \\
\hline \multicolumn{8}{|l|}{ Lymphadenectomy } \\
\hline Yes & $17(58.6)$ & $12(41.4)$ & 58 & & \multirow[t]{2}{*}{ NS } & 84 & \multirow{2}{*}{ NS } \\
\hline No & $28(62.2)$ & $17(37.8)$ & 44 & & & 79 & \\
\hline
\end{tabular}




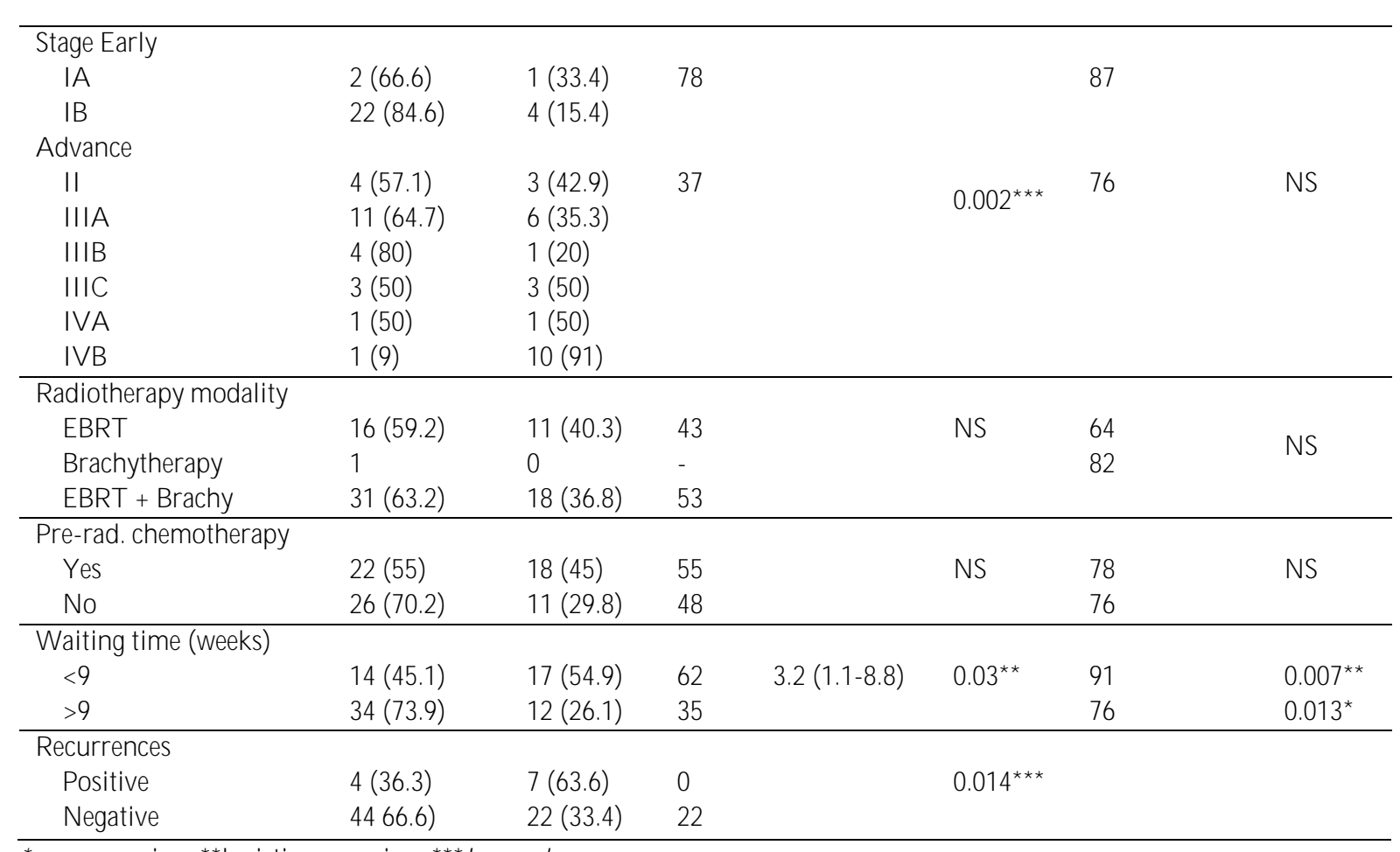

*cox regression; **logistic regression; ***log-rank

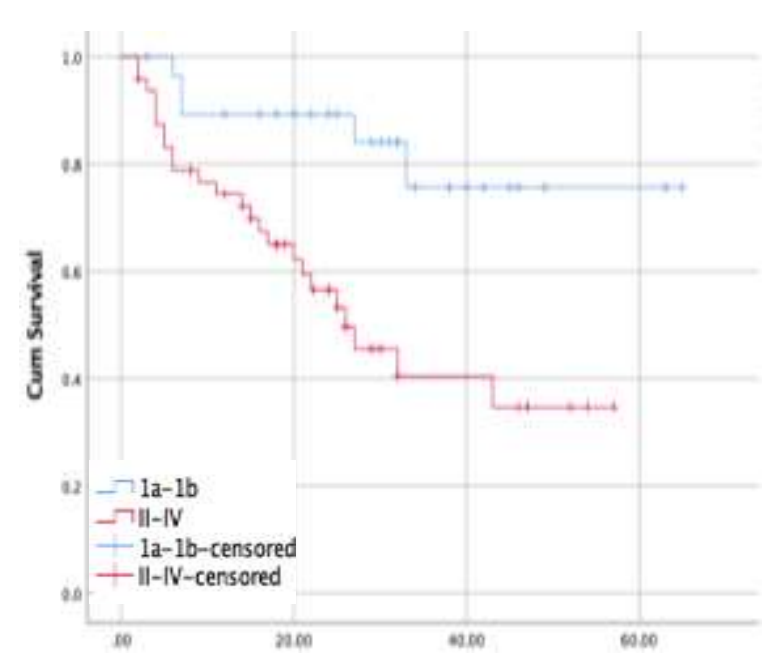

Figure 1: Kaplan-M eier curve for stadium

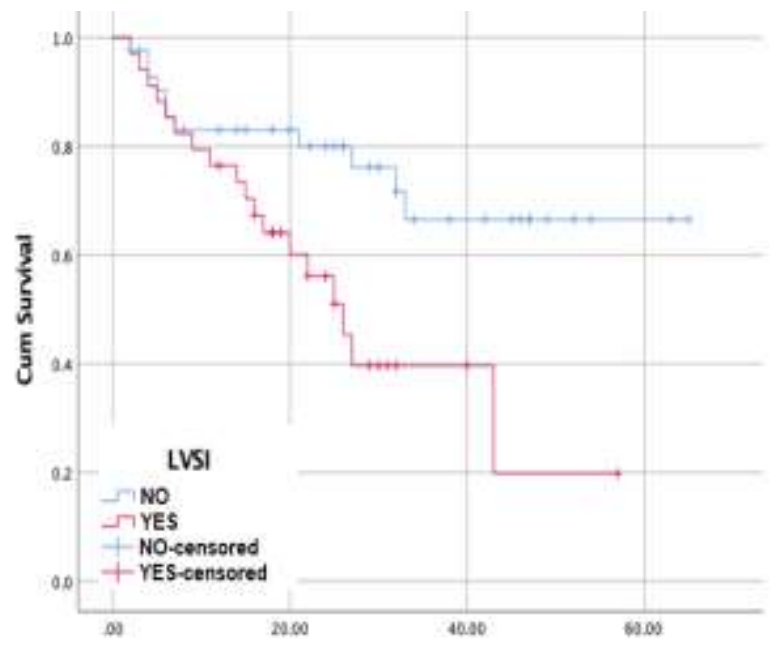

Figure 2: Kaplan-M eier curve for LVSI . 


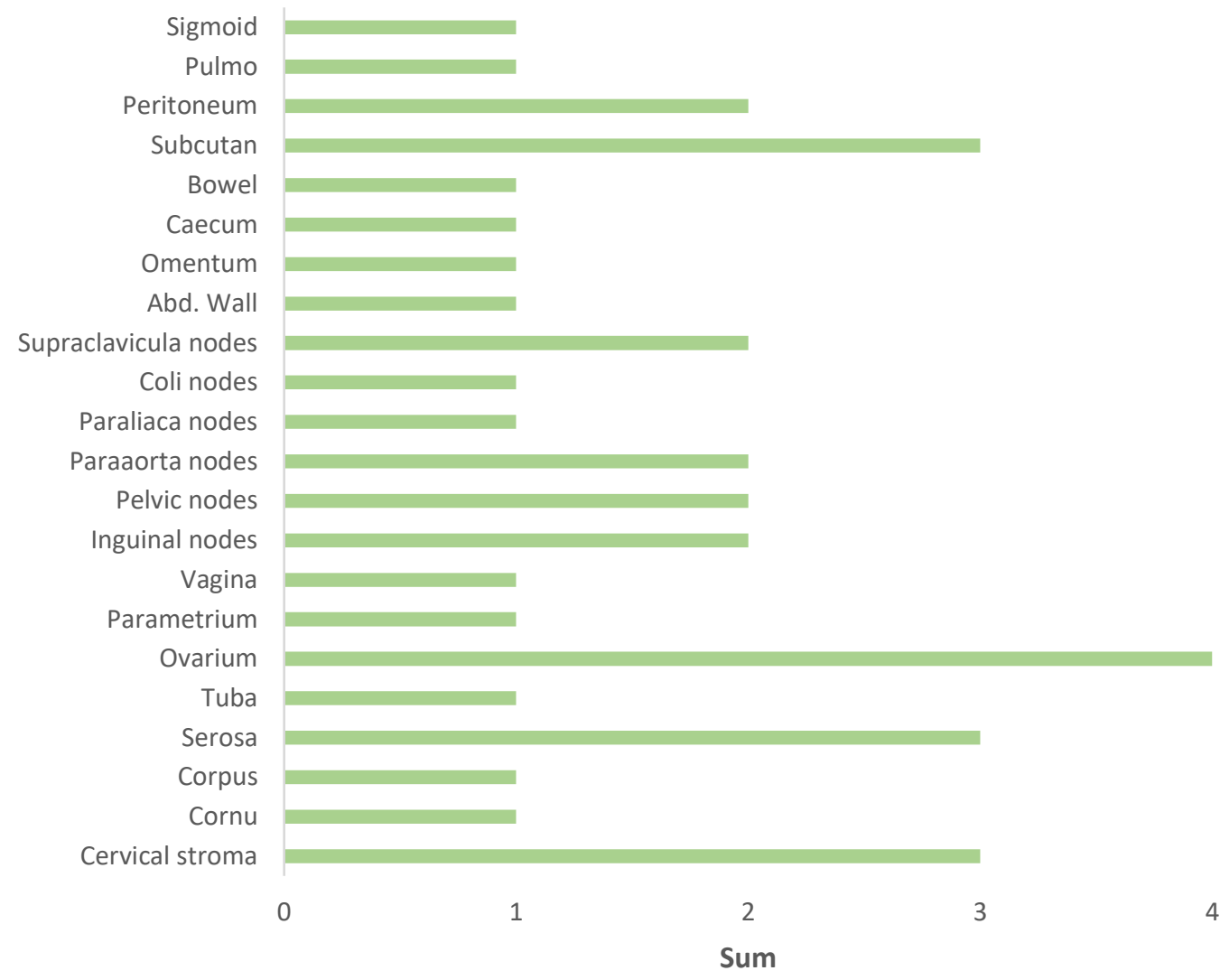

Figure 3: M etastasis distribution

Table 4: Effect of radiotherapy modality on adverse effect

\begin{tabular}{|c|c|c|c|c|c|}
\hline \multirow{2}{*}{ Modality } & \multicolumn{3}{|c|}{ Adverse effect } & \multirow{2}{*}{ No adverse effect } & \multirow{2}{*}{$\mathbf{p}$} \\
\hline & GI tract & GU tract & Both & & \\
\hline EBRT $(n=27)$ & 12 & 3 & 3 & 9 & \\
\hline EBRT + Brachytherapy $(n=49)$ & 15 & 7 & 6 & 21 & NS \\
\hline Brachytherapy ( $n=1$ ) & 0 & 0 & 0 & 1 & \\
\hline
\end{tabular}

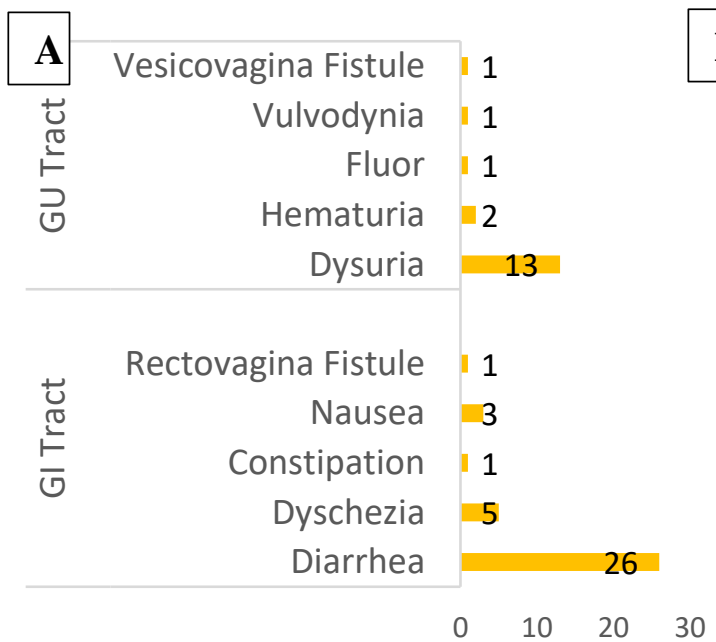

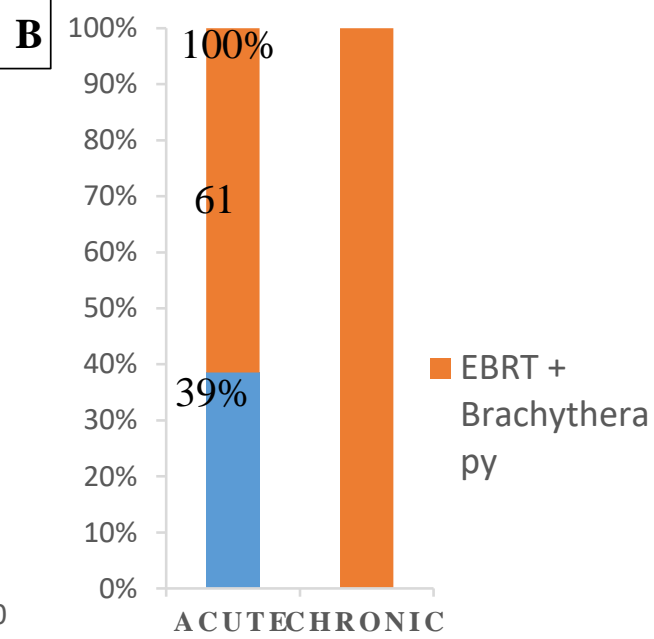

$\mathrm{EBRT}=$ External Beam Radiotherapy; $\mathrm{GI}=$ gastrointestinal; $\mathrm{GU}=$ genitourinary; $\mathrm{NS}=\mathrm{N}$ ot significant

Figure 3: A. Symptoms distribution of GI tract and GU tract; B. Modality percentage to onset of adverse effect. 
non-obese group ( $77 \%$ vs $43 \%$ ). This study found $44.1 \%$ cases with LVSI positive. In group of LVSI positive, the OS was $0 \%$, and logistic regression test found $p=0.02$ with $\mathrm{OR}$ of $0.3(\mathrm{Cl}$ $95 \%$ 0.1-0.8). Significant result of logistic regression test was also found in DFS-3 years with $p$ value of 0.004 . Stage classification was divided into early stage and advanced stage, and had significant different for OS of $78 \%$ vs $37 \%$. In identifying the metastasis distribution, grouping of data according to metastasis location was performed as seen on Figure 3. Nine weeks of waiting time in this study was taken from the previous study which stated that nine weeks of waiting time could affect outcome of high risk endometrial cancer. In this study, group of patients whose waiting time for radiotherapy $>9$ weeks significantly had worse OS and DFS-3 years, $35 \%$ and $76 \%$, respectively. From logistic regression test, the OR for OS was 3.2 (CI 95\% 1.1-8.8) with $p$ value of 0.03 . Recurrences occurred $14.3 \%$. In survival analysis test, patients with recurrence history had OS $0 \%$ with log-rank test $p$ value $=0.001$.

\section{Adverse Effect}

Radiotheraphy also could cause adverse effects as summarized in Table 4. This study performed analysis of radiotheraphy modality roles to adverse effect event. The adverse effects were classified to gastrointestinal and genitourinary tract, also acute and chronic effect. In Figure $3 \mathrm{~A}$, diarrhea and dysuria are the most frequent symptoms. Adverse effects occurred in combination modality of $61 \%$ as shown in Figure 3B. The statistical analysis of modality to adverse effect and onset of adverse effect showed no significant result.

\section{DISCUSSION}

Overall survival and DFS-3 years of patients with positive LVSI prognostic factors were lower than negative LVSI. Overall survival and DFS-3 years with prognostic factors of age $\geq 60$ years and $B M I>30 \mathrm{~kg} / \mathrm{m}^{2}$ were better than age $<60$ years and BMI $<30 \mathrm{~kg} / \mathrm{m}^{2}$. O verall survival and DFS-3 years in the queuing group $>9$ weeks were lower than $<9$ weeks. Combination of radiotherapy modalities more often caused side effects than the external radiation group alone.

\section{OSandDFS-3years}

Age is one of the prognostic factors that can determine whether or not adjuvant radiotherapy is needed. The results of this study indicated that $O S$ in the $<60$ years age group was significantly lower than the $>60$ years age group, and the DFS-3 year rate was significantly lower than the $\geq 60$ years group of $78 \%$ vs $82 \%$. The results of this study were different from the results of other studies in general. Findings that might influence the results of the age group analysis in this study might be due to deep invasion (>50\%) occurring more in the $<60$ years age group ( 37 vs 29 ). Determination of the role of age as a prognostic factor is still different among researchers. M ost researchers stated that the older the age, the worse the patient's prognosis, however there is no agreed consensus $(15,16)$. A 12-year cohort study said that age was not a prognostic factor in endometrial cancer (17). A nother study said that no significant relationship was found for the effect of age on the incidence of recurrence in grade 3 endometrial cancer (18).

Obesity is a risk factor for endometrial cancer, especially the endometrioid type, which is estrogen dependent. The relationship between IMT and OS is still controversial. Some studies say that increasing body mass index actually improves overall survival. This study significantly showed that the BM I group $\geq 30 \mathrm{~kg} / \mathrm{m}^{2}$ had better survival outcomes. Other studies mention similar results $(19,20)$. The effect of BMI in this study might also be influenced by staging. In this study, all cases of stage IV A and IV B were in the BMI group $<30$ $\mathrm{kg} / \mathrm{m}^{2}$, where 10 out of 11 cases of stage IV B died.

The histopathological type of endometrioid has a better prognosis than the non-endometrioid type. In this study, the type of histopathology did not have a significant relationship to overall survival. Differences in OS results with other studies may be caused by differences in staging at the time of therapy. For the endometrioid type, 11 cases of stage IVB were found in which 10 cases died. Whereas, for the type of clear cell carcinoma, of the eight cases of clear cell carcinoma, six cases constituted the initial stage (IA and IB), and two cases of stage III with only one patient's mortality.

The presence of LVSI is an important prognostic factor that can affect recurrence and OS. LVSI increases the risk of regional recurrence and metastasis compared to groups without LVSI for all grades, invasions and stages (21). This study showed the same results with other studies that OS in the positive LVSI group was lower than the negative LVSI group (22). The importance of LVSI is also shown by U harcek's research which states that the effect of LVSI is not related to the depth of invasion or grade (23).

Determination of staging in endometrial cancer refers to the consensus of FIGO (2010). In this study, the early-stage group (IA-IB) had OS 78\% better than the advanced-stage group (II-IV). These results were in accordance with recent studies (91\% vs $52.2 \%$ ) (24). A nother study conducted in 2017 showed that the higher the stadium, the lower 5-year OS number regardless of histopathological type (25).

List of radiotherapy queues at dr. Soetomo Hospital is quite long even up to six months. The radiotherapy delay $>9$ weeks is a significant prognostic factor for recurrence and has a lower OS (13). The results of the analysis found that the queuing group $<9$ weeks had OS $62 \%$ better than the queuing group $>9$ weeks with 0 S $35 \%$. In the logistic regression test, $p=0.03$ was obtained with an OR of $3.2(95 \% \mathrm{Cl} 1.1-8.8)$. These results were in line with previous report where in a group of patients with queues $>9$ weeks had a 2.07-fold risk of mortality (13). Queues have also been shown to significantly affect DFS-3 years and therapeutic response. The most frequent cause of long queues in dr. Soetomo Hospital is because the number of patients is not proportional to the number of radiotherapy tools and reasons for improving general conditions, other reason is not well documented in the medical record. The reasons for improving general conditions and logistical reasons are the most common reasons encountered (13). Delayed therapy in endometrial cancer can affect the proliferation and doubling time of endometrial cancer cells. Doubling time in endometrial studies has been investigated and the results of 
the study showed that within 120 hours, the endometrial cancer cell proliferation index was three times (26).

In this study, recurrence cases occurred in 11 cases (14.2\%), and the results of statistical tests showed significantly lower OS than the group without recurrence. The majority of cases in this study was case of endometrioid type with grade 3 histopathology type. The results of this study were in accordance with other reports which stated the recurrence rates in grade 3 endometrioid were $19.6 \%, 23.6 \%$ and $13.7 \%$, respectively (18)

\section{Adverse Effect}

In this study, the majority of side effects occurred due to the combined modality of external radiation and brachytherapy (61\% vs $39 \%)$. Besides, the combination modality in this study was a cause of chronic intoxication in the gastrointestinal tract and genitourinaria, but the results of statistical tests did not show significant differences. These results were in accordance with another study which compared the side effects of combination modalities (external radiation + brachytherapy) and brachytherapy alone. The results of the study showed that groups with combined modalities had higher incidence of side effects and mortality than brachytherapy alone (27).

The location of the uterus is close to the gastrointestinal tract and the genitourinary tract, so that adverse events are more common in these two organ systems. In this study, the most common side effect of the gastrointestinal tract was diarrhea, similar to the results of a study from Post O perative Radiation Therapy in Endometrial Cancer-1 (PORTEC-3) which mentioned $21 \%$ of diarrhea side effects (28). The occurrence of intoxication in the gastrointestinal tract may be explained by the fact that after intestinal mastectomy fill the empty space previously filled with the uterus, so more areas are affected by external radiation and also closer to the brachytherapy applicator (29). The most common complaint of genitourinaria after radiotherapy was pain during urination (dysuria). These results were consistent with Bradley and McHaffie's research which stated that postradiotherapy cystitis is a common complication with complaints of dysuria, frequency, urgency, and nocturia (30). Basically, the bladder can tolerate adjuvant doses which are commonly used in radiotherapy better than the intestine (45$50 \mathrm{~Gy}$ ). Five-year observations made by PORTEC - 1 which evaluated the effects of adjuvant radiotherapy on endometrial cancer at doses up to $46 \mathrm{G}$ y showed that no serious side effects were found in the genitourinary system (30). Two cases of fistula were found in this study, vesicovagina fistula and rectovagina fistulae. Cases of post-radiotherapy rectovagina and vesicovagina fistulae are rare, but are serious complications. Some cases of fistulae occur due to the administration of high doses to control cases of vaginal metastases or adjacent organs (31). In the case of fistulas with vaginal necrosis, hyperbaric oxygen and pentoxifiline therapy can be performed (30). Pentoxifilne is a bloodflowing agent, can increase the number of erythrocytes, and increases the flexibility of leukocytes (32).

This study has limitations due to a retrospective study where it cannot control confounding or biased variables, but as in survival research in the field of oncology in general, evaluating the success of therapy for a very long time makes it difficult for researchers to conduct prospective research and is also has ethical cleasrance issue.

\section{CONCLUSION}

Overall survival and DFS-3 years of patients with positive LVSI prognostic factors were lower than negative LVSI. Overall survival and DFS-3 years with prognostic factors of age $\geq 60$ years and $\mathrm{BMI}>30 \mathrm{~kg} / \mathrm{m}^{2}$ were better than age $<60$ years and BMI $<30 \mathrm{~kg} / \mathrm{m}^{2}$. Overall survival and DFS-3 years in the queuing group $>9$ weeks was lower than $<9$ weeks. Combination of radiotherapy modalities more often causes side effects than the external radiation group alone.

\section{REFERENCES}

1. Bendifallah S, Ilenko A, Daraï E. High risk endometrial cancer: Clues towards a revision of the therapeutic paradigm. J Gynecol Obstet Hum Reprod. 2019 Dec;48(10):863-71.

2. Chen L, Dizon DS. Endometrial carcinoma: Epidemiology, risk factors, and prevention.

3. Geels YP, Pijnenborg JMA, Gordon BBM, Fogel $M$, Altevogt $P, M$ asadah $R$, et al. L1CAM Expression is Related to Non-Endometrioid Histology, and Prognostic for Poor Outcome in Endometrioid Endometrial Carcinoma. Pathol Oncol Res. 2016;22(4):863-8.

4. Sofyan N, Tjokroorawiro B, Sandi I. Gambaran Pasien Kanker Endometrium Di Rsud Dr. Soetomo Surabaya Tahun 2016 (Ditinjau Dari Beberapa Faktor Risiko Yang Telah Diketahui). Universitas A irlangga; 2018.

5. Fleming G, DiSilvestro P. Uptodate: Adjuvant treatment of high-risk endometrial cancers [Internet]. 2019 [cited 2019 Jun 20]. Available from: https://www.uptodate.com/contents/adjuvanttreatment-of-high-risk-endometrialcancers?search=adjuvant-treatment-of-high-riskend\&source=search_result\&selected $\mathrm{T}$ itle $=1 \sim 150 \&$ usa ge_type $=$ default\&display_rank $=1$

6. M ingels MJJM, M asadah R, Geels Y P, Otte-Höller I, De Kievit I M , V an Der Laak JA W M , et al. High prevalence of atypical hyperplasia in the endometrium of patients with epithelial ovarian cancer. Am J Clin Pathol. 2014;142(2):213-21.

7. Lubis HP, Aldiansyah D, Siregar HS, Rivany R, H ariadi TS. Expression of natural killer cell activity with CD107a on ectopic endometrium in woman with endometriosis compared with non-endometriosis. In: IOP Conference Series Earth and Environmental Science. 2018.

8. Adenin I, Lutan D, Tandjung T, Suheimi HK, Siregar MFG. Serum prokineticin-1 (endocrine gland vascular endothelial growth factor) as an alternative marker for assessing endometrium receptivity. G Ital di Ostet e Ginecol. 2018;40(4):158-64.

9. Plaxe SC, M undt AJ, Dizon DS. Approach to adjuvant treatment of endometrial cancer. 
10. 10. Creutzberg CL, N out RA. The role of radiotherapy in endometrial cancer: current evidence and trends. Curr Oncol Rep. 2011 Dec;13(6):472-8.

11. 11. Rahestyningtyas $E$, M ulawardhana $P$, Lesmana $T$. Abdominal skin metastasis in endometrial cancer. $M$ aj Obstet Dan Ginekol. 2019;27(2):82-9.

12. 12. Yashar CM. Basic principles in gynecologic radiotherapy. In: Clinical Gynecologic Oncology. Elsevier; 2018. p. 586-605.

13. 13. Cattaneo R 2nd, Hanna RK, Jacobsen G, Elshaikh MA. Interval between hysterectomy and start of radiation treatment is predictive of recurrence in patients with endometrial carcinoma. Int J Radiat Oncol Biol Phys. $2014 \mathrm{M}$ ar;88(4):866-71.

14. 14. Catherine $C$, Camellia V, Husada MS, Loebis $B$, Effendy $E$, Amin MM. Affective psychopathology towards the quality of life of breast cancer patients with radiotherapy in medan, Indonesia. O pen Access M aced J M ed Sci. 2019;7(9):1456-60.

15. 15. Britton LC, Wilson TO, Gaffey TA, Lieber M M, Wieand HS, Podratz KC. Flow cytometric DNA analysis of stage I endometrial carcinoma. Gynecol Oncol. 1989;34(3):317-22.

16. 16. Moradokkasem $W$, Saeaib $N$, Liabsuetrakul $T$. Disease Free Survival of Stage I Endometrial Cancer after Surgery with or without Adjuvant Treatment. Folia M edica Indones. 2019;55(1):37-42.

17. 17. Mundt AJ, Waggoner $S, Y$ amada D, Rotmensch J, Connell PP. A ge as a prognostic factor for recurrence in patients with endometrial carcinoma. Gynecol Oncol. 2000;79(1):79-85.

18. 18. Wang J, Jia N, Li Q, Wang C, Tao X, Hua K, et al. Analysis of recurrence and survival rates in grade 3 endometrioid endometrial carcinoma. Oncol Lett. 2016;12(4):2860-7.

19. 19. Temkin SM, Pezzullo JC, Hellmann M, Lee Y-C, Abulafia $O$. Is body mass index an independent risk factor of survival among patients with endometrial cancer? Am J Clin Oncol. 2007;30(1):8-14.

20. 20. Münstedt $K, W$ agner $M$, Kullmer $U, H$ ackethal $A$, Franke FE. Influence of body mass index on prognosis in gynecological malignancies. Cancer Causes Control. 2008;19(9):909-16.

21. 21. Mariani A, Webb MJ, Keeney GL, A letti G, Podratz $K C$. Endometrial cancer: predictors of peritoneal failure. Gynecol Oncol. 2003 M ay;89(2):236-42.

22. 22. Weinberg LE, Kunos CA, Zanotti KM. Lymphovascular space invasion (LVSI) is an isolated poor prognostic factor for recurrence and survival among women with intermediate- to high-risk earlystage endometrioid endometrial cancer. Int J Gynecol cancer Off J Int Gynecol Cancer Soc. 2013 Oct;23(8):1438-45.

23. 23. Uharcek $P$. Prognostic factors in endometrial carcinoma. J Obstet Gynaecol Res. 2008 Oct;34(5):776_ 83.
24. 24. Tejerizo-García A, Jiménez-López JS, MuñozGonzález JL, Bartolomé-Sotillos S, M arqueta-M arqués L, López-González G, et al. Overall survival and disease-free survival in endometrial cancer: prognostic factors in 276 patients. Onco Targets Ther. 2013;9:1305-13.

25. 25. Kosary CL. Chapter 15: Cancer of the corpus uteri. Ries LA G, Young JL, Keel GE, Eisner M P, Lin YD HM J, Ed SEER Surviv Monogr Cancer Surviv Among Adults US SEER Progr. 1988;2001.

26. 26. Koval OA, Sakaeva GR, Fomin AS, Nushtaeva AA, Semenov D V, Kuligina $E V$, et al. Sensitivity of endometrial cancer cells from primary human tumor samples to new potential anticancer peptide lactaptin. J Cancer Res Ther. 2015;11(2):345.

27. 27. Onsrud $M$, Cvancarova $M$, Hellebust TP, Tropé CG, Kristensen GB, Lindemann $K$. Long-term outcomes after pelvic radiation for early-stage endometrial cancer. J Clin Oncol. 2013;31(31):3951-6.

28. 28. de Boer SM, Powell ME, M ileshkin L, Katsaros D, Bessette $P$, Haie-Meder $C$, et al. Adjuvant chemoradiotherapy versus radiotherapy alone for women with high-risk endometrial cancer (PORTEC3): final results of an international, open-label, multicentre, randomised, phase 3 trial. Lancet Oncol. 2018;19(3):295-309.

29. 29. Herrera FG, Santa Cruz O, A chtari C, Bourhis J, Ozsahin M . Long-term outcome and late side effects in endometrial cancer patients treated with surgery and postoperative radiation therapy. Ann Surg Oncol. 2014;21(7):2390-7.

30. 30. Bradley KA, M CHaffie DR, M undt AJ, Dizon DS. Treatment-related toxicity from the use of radiation therapy for gynecologic malignancies. Uptodate W altham, M A W olters-Kluwer. 2018;

31. 31. Betalli P, De Corti F, M inucci D, Mazzarotto R, Meneghini L, Bisogno $G$, et al. Successful topical treatment with mitomycin-C in a female with postbrachytherapy vaginal stricture. Pediatr Blood Cancer. $20080 \mathrm{ct} ; 51(4): 550-2$.

32. 32. McCarty MF, O'Keefe JH, DiNicolantonio JJ. Pentoxifylline for vascular health: a brief review of the literature. Open Hear [Internet]. 2016 Feb 8;3(1):e000365-e000365. Available from: https://pubmed.ncbi.nlm.nih.gov/26870389 